\title{
Initial Motivation and Pedagogical Support of Physical Education Students of Unipampa-RS
}

\author{
Marcio Cossio Baez ${ }^{1}$, Juan José Mouriño Mosquera², Claus Dieter Stobäus ${ }^{3}$ \\ ${ }^{1}$ Graduate Program of Physical Education, UNIPAMPA-Federal University of Pampa, Uruguaiana, Brazil \\ ${ }^{2}$ Postgraduate Program in Education, Pro-Rectory of Postgraduateand Research, Pontifical Catholic University of Rio Grande do \\ Sul, Porto Alegre, Brazil \\ ${ }^{3}$ Postgraduate Programs in Education and in Biomedical Gerontology, Pontifical Catholic University of Rio Grande do Sul, Porto \\ Alegre, Brazil \\ Email: stobaus@pucrs.br
}

How to cite this paper: Baez, M. C., Mosquera, J. J. M., \& Stobäus, C. D. (2017). Initial Motivation and Pedagogical Support of Physical Education Students of UnipampaRS. Creative Education, 8, 1401-1414. https://doi.org/10.4236/ce.2017.89098

Received: March 14, 2017

Accepted: July 24, 2017

Published: July 27, 2017

Copyright (c) 2017 by authors and Scientific Research Publishing Inc. This work is licensed under the Creative Commons Attribution International License (CC BY 4.0)

http://creativecommons.org/licenses/by/4.0/

\section{Open Access}

\begin{abstract}
Joining in Higher Education brings with it a range of new life learning of the young students, in any university course. Often the students are surprised positively when faced with different realities than they had previously lived, due to their lack of experience. The entire thesis is about the process of building well-being and quality, supported on literature revision, with interfaces of Positive Psychology field. This excerpt of the theoretical contributions and a quantitative part, aimed to accompany the education process of Physical Education with 100 (from a 147 invited students, at the Federal University of Pampa-UNIPAMPA, in Uruguaiana-Rio Grande do Sul, Brazil, who answered the Assessment of Initial Motivation and Pedagogical Support Questionnaire (which examines factors of admission in the higher course frequented and factors of choice of the teaching profession), attending four of the eight semesters of bachelor degree. The most relevant results were: high Initial Motivation Assessment and Pedagogical Support with a mean of 26.16 points $(\mathrm{SD}=$ 5.36); Educational Training Model evidencing valorization of this process, average 58.85 points $(S D=7.73$ ); Professional Results pointing to a positive perspective regarding the professional future, average 29.28 points $(\mathrm{SD}=$ 3.65); good support in the internship with an average of 49.69 points $(\mathrm{SD}=$ 8.75). We could contrast the results with other previous studies, this being considered smaller. It is necessary to construct experiences in more realistic university spaces and to provoke learning at higher and positive levels of well-being, through support for constructive practical and theoretical experiences, insertion in richer experiences in inner and outside school environments, participation in study groups and, mainly, by a better continuous professional appreciation of the Physical Educator.
\end{abstract}




\section{Keywords}

Education, Motivation, Pedagogical Support, Student Well-Being, Physical Education

\section{Introduction}

Taking as a starting point discuss about the educational (trans) formation of the student in the teacher, we can observe that the general formation is devalued, considering what the importance is, on the one hand, the specific formation in terms of the learning of the contents that the teacher must teach to his students and, on the other hand, the professional experience to learn strategies that allow the teacher to conduct more effectively the process of teaching content. It occurs also in Physical Education, so we are interested in studying this field.

Our research excerpt, in this article we point out a reflection about theoretical support and part of data analysis of part of Baez (2015) Thesis, and our discussion as authors in the addressed themes.

In short, as previously explained, the study seeks to deepen knowledge of the personal and professional trajectory of the student who becomes a teacher and their relationship with aspects of teacher well-being.

\section{Literature}

In the study of Jesus (1996), bachelor degree students in different courses in a European university at Coimbra, in Portugal, perceived themselves with satisfactory resources to deal with stressful factors, coupled with feelings of pleasure and joy, there are so-called "protective factors", which are basically personal health skills and abilities. Among the components of well-being are satisfaction with life and the balance of positive and negative endearment, including the notion of cognitive evolution, quality of life and affective relationships.

Sampaio, Baez, Stobäus \& Oliveira (2012), with a survey with 682 High School students(303 male and 379 female, 538 from public schools and 144 from private schools) in Uruguaiana-RS, Brazil, about the 'problems in the classes' of Physical Education, says that:

The format of the classes has been widely discussed, because nowadays the students are in another generation, involved in technology, in fast communication, under the influence of the media and institutions are not keeping pace. This is mainly reflected in the high school, according to the age group, the students are at the height of adolescence, suffering countless transformations and influences, preoccupied with vestibular, job market, social interaction and still questioning traditional classes that do not motivate and remain in the binomial sport-competition. Therefore, this research aims to investigate the main factors that contribute to demotivation and avoidance of the class. 
The direct repercussions of these "chronic situations" in our Brazilian schools encourage them to continue their studies in order to try to help in a more positive way. These problems and possible solutions must be discussed at Physical Education course at the university, so that their education in bachelor degree.

Santos, Antunes, Mosquera \& Stobäus (2016: p. 2016) described that "teaching and learning processes related to the Motivational Process and reviews elements of the conceptualization of motivation, as a process who involves external/ extrinsic and internal/intrinsic components, including elements of interpersonal relationships".

Complemented Santos, Antunes, Mosquera \& Stobäus (2016: p. 2015) that, for Deci \&Ryan $(1985,2000)$ :

[...] intrinsic motivation corresponds to a typically self-determined behavior, in which the interest in an activity is guided by free choice, by spontaneity and curiosity. The efforts dedicated to the realization of an activity are not linked to external contingencies and rewards, but with the inherent characteristics to activity. They highlighted that in which tasks have ends themselves, theorists report that intrinsically motivated behavior is more associated with feelings of satisfaction, fulfillment and pleasure

About extrinsic motivation, they reinforced that:

[...] activity or task is subject to the achievement of a goal or outcome, and in this situation the realization of actions is closely related to rewards, reviews, terms, punishments, praise, among others. What determines the behavior is much more associated with the control, touted by external wills in which the individual acts under pressure, to the detriment of free will and autonomy. In this controlled behavior, the subject tends to perceive the activities/tasks as instrumental for achieving certain goal.

Throughout the Physical Education course, in the most universities at Brazil, students are required to have greater autonomy to participate in curricular and extracurricular activities, such as lectures, courses, congresses and others complementary activities, so that they can study and apply the knowledge and abilities at the course, be corrected and/or reinforced before inserted in the reality, with supervision. There must be a kind of 'protective factors' or attitudes from their teachers and the global environment at their education in the university, such as moments of possibility to discussions, study groups, pedagogical and psychological support.

In our country, College students, as well as in their entire schooling, there exists moments of vulnerable to a wide range of threats to their well-being, according Baez (2008), such as global and local situations outside the school (economy, politics, environment), family problems (income, parents previews studies, parents jobs and aspirations, motivational environment), and also their own capacities, abilities and attitudinal responses.

In the initial education processes of a future Physical Education teacher, it is important to enable cognitive challenges so that the academic is led to reflect on 
the reality in which he will be inserted and, from it, to enable him to solve the problems that he will face since his formation to their practice in the labor market. But the emotional challenges, and consequent changes, in a more positive way to understand the others and him/herself have the same importance, mostly when using Positive Psychology as a reference. There is a great relation between cognition and emotion, according the Positive Psychology, proposed by Seligman (2012), and Baez, Stobäus \& Mosquera (2014).

The debate about malaise and well-being has been passing through the time and the educational models instituted in our education schools. From this point of view, we can say that ideas on this topic, which we are developing, Baez, Stobäus \& Mosquera (2016) emphasize the search for better university structures that contribute to the improvement in the quality of life of educational professionals, such as our teachers and their students. This shows the need for these continuous studies that can reveal the process faced by our teachers and students, from their formation to their actual performance in educational environments.

They say that "family influences were top themes in the choice of teaching as a career. Female teacher candidates also indicated that they wanted to become teachers because their parents thought that becoming a teacher was suitable for females". These reality is different ours.

In our previews article, Baez, Stobäus \& Mosquera (2014), about the relations between aspects of the initial education in Physical Education related to more effective (Full) Inclusion processes, taking account on the motivation theories and the Positive Psychology, we described also that there are some differences in the responses of the students during the course and about themes as education, preparation to be a teacher, the anxiety at the finishing course moments, the first year of insertion on their job and their new practices. So we recommended the use of elements of the Positive Psychology, beginning at the graduation and posterior continuous education, to receive better supports for their activities as teachers.

Damasio (2011) emphasizes the relation between cognition and affectivity in human relationships, to reduce the differences between humans.

Mosquera \& Stobäus (2016) says that in education it is very important, and apply these ideas to interpersonal aspects that must be developed, since we born and come into human socialization, mostly when there are implications to the educational and care processes, as caregivers (educators, physicians, and other health professionals).

These approaches confirm our intention to investigate the context in which the future teacher is inserted in pedagogical training in the undergraduate courses in Physical Education, at our university, reflecting on his personal and professional prepare, aiming to constitute more positive references that enable new actions that promote well-being in their future teaching.

In our country, the issues of regulation of Physical Education as a profession and areas, or health rather than education, have been generating some discussion. 
Currently, physical activity has been gradually added to society as a factor of health and well-being, through sports, dance, gymnastics, recreation and also activities with a softer focus such as alternative body practices. This fact broadens the range of professional activity, not only restricted to primary and secondary schools, creating a new dynamic in the labor market.

According Brazilian National Council of Education, the Physical Education guidelines propose the formation of a professional profile aimed at understanding the social context of individuals and communities in order to intervene professionally with their academic specialty and with the expansion of knowledge, adopt healthy habits. Every curricular proposal aims at providing a complete and adequate training to the demands placed on the profession. However, because of the dedication and commitment of those who assign themselves the task of constructing higher education curricula, there are always elements that escape perception. Based on these affirmations, it is desired that the professional in Physical Education has a huge range of skills and abilities to develop their activities, in direction to a supporting health education.

\section{Characterization of the Study}

Thus, the delimitation of the research problem for this study was investigate about the personal and professional experiences of how bachelor degree Physical Education students and in their first year as teachers does the process of building well-being and quality of life, analyzing data and reports on aspects of student well-being, positive and negative effects on self-image and self-esteem, during their education.

The Thesis excerpt presented here is about part of the quantitative data, of the bachelor degree students with, according Baez (2015: p. 16):

[...] 100 scholars over four semesters answered instruments that assessed initial motivation and pedagogical support, educational training model, professional results, support for the stage, self-image and self-esteem, positive and negative affects (at Panas), the assessment of good subjective-being, quality of life (at Whoqol-BREF). In the second phase, the total interviewed 14 academics who responded to questions about their training and building strategies for the construction of well-being. Later more were interviewed four former students, recent graduates, about the experiences after their training and insertion in the labor market.

The research process of Baez Thesis was guided by the methodology that best evidences the object under study, clarifying the central issue and allowing a precise analysis, suggested by Minayo (2001), of the information collected, in order to create a gear that guarantees a good scientific identity, with the interfaces between the analysis of quanti and qualitative data.

This article contemplates part of the quantitative data, offering support for research during the undergraduate course in Physical Education, analysis was performed using the statistical software SPSS, version 17.0. 


\section{Study Field}

For the research, the Federal University of Pampa, in the city of Uruguaiana-RS, in the south of Brazil, frontier with Argentine, was chosen for its ease of access and greater availability in scheduling with students and is the workplace of Baez. The course has eight theoretical-practical semesters, with supervised stages during the entire course, all developed at the university campus and schools with internship and practices links at the city.

An explanation is necessary, since as the UNIPAMPA Education course is characterized as a new course, started on 2008, and has a curriculum that, in front of many undergraduate courses in Physical Education in our country, can be considered innovative, because it allows the insertion of the academics into the school from the first semester, through Curricular Pedagogical Practices. This seeks through the various disciplines developed in the academic semesters to provide the real practice, i.e., the accomplishment of activities developed in the academic environment in the school environment where effectively the future professional will perform their teaching practice.

Supervised internship is one of the most important stages in the academic life of undergraduate bachelor degree students and, following the requirements of the Brazilian National Education Guidelines and Bases Law, from 2006, onwards it constitutes a proposal for Supervised internship with the objective of providing the student with the observation, research, planning, execution and evaluation of different pedagogical activities, with direct approximation of academic theory with classroom practice.

The internship is the central axis in teacher training, because it is through this that the professional knows the aspects that are indispensable for the formation of the construction of the identity and the day-to-day knowledge.

Internship also becomes essential in the teacher training process, as it provides conditions for future educators, specifically undergraduate students, a close relationship with the environment that involves the daily life of a teacher and, from this experience, academics will begin to understand themselves as future teachers, for the first time facing the challenge of living, speaking and listening, with languages and knowledge that are different from their environment, more accessible to the child.

Thus, the supervised stage gives the licensee the mastery of theoretical and practical instruments essential to the performance of his duties. The purpose of this exercise is to benefit from the experience and promote the development, in the professional field, of the theoretical and practical knowledge acquired during the course in the higher educational institutions, as well as, to promote, through various educational spaces, the expansion of the universe Cultural background of academics, future teachers.

According Brazilian National Council of Education, the Physical Education guidelines propose the education of a professional profile aimed at understanding the social context of individuals and communities in order to intervene professionally with their academic specialty and with the expansion of knowledge, 
adopt healthy habits. Also, the bachelor degree in Physical Education, must be conceived, planned, operationalized and evaluated aiming at the acquisition and development of specific skills and abilities that contemplate the perspective of the promotion of health in the different spheres of action of these professionals.

So, every curricular proposal aims at providing a complete and adequate training to the demands placed on the profession. However, because of the dedication and commitment of those who assign themselves the task of constructing higher education curricula, there are always elements that escape perception.

Based on these affirmations it is desired that the professional in Physical Education has a huge range of skills and abilities to develop their activities.

In the population and sample aspects, all the academics enrolled in the undergraduate degree in Physical Education of UNIPAMPA were invited to participate, totaling 147 students, and 100 of theme filled the instrument.

The sample was delimited in 100 academics who answered (from these 147), from four $\left(2^{\text {nd }}, 4^{\text {th }}, 6^{\text {th }}\right.$ and $\left.8^{\text {th }}\right)$ of the eight semesters who accepted to participate in the study. The distribution in the sample was similar to male and female, and the ages were between 18 and 36 years old students.

The construction of the Thesis begun in 2011-2, with the literature revision, discussion at a group of teachers and students at the university, interested on the themes, the construction of these research was possible with the discussion with these participants and Baez delimitate the research, with the orientations during the Thesis construction, supported on literature, the contacts with Jesus' instrument and their permission to use them.

The study was then defended to qualification, and submitted to the Scientific Committee of PUCRS (protocol no. 192/2014), which it considered necessary to send to the Ethics Committee. Upon approval, the project is registered in the Brazil platform, according to resolution 466/12, which had received approval, no. 808.522. The students were invited in their classrooms, and those who want participate received the orientations and guidelines about the purposes of the research, filled the Informed Consent Term, and then answered the instrument, in other room, according the day of their classes, time (the course is evening, from 19.00 to 22.30), using no more than $1 \mathrm{~h}$.

Data were collected in 2012-3, with Baez supervision, and the analyses were between 2013-4.

For the evaluation of the initial Motivation and Pedagogical Support, as instrument, we used the Initial Motivation Assessment and Pedagogical Support Questionnaire, proposed by Jesus (1996), (no translation to English still now) was used to evaluate the initial motivation for the profession teacher. In terms of the motivational orientation for this profession, the author posed two questions: the first concerning the factors of entrance in the attended upper course and the second to the factors of choice of the teaching profession, and pointed also 11 subscales (Professional project, Professional commitment, Goal Value, Expectation of success, Expectation of effectiveness, Control Expectation, Assignmentsuccesses, Assignment-failures Locus, Assignment-successes Locus, Stability 
Assignment-failures, Stability Intrinsic motivation) obtained Cronbach alpha coefficients between 0.608 and 0.913 at these subscales. The further applications gave similar results.

In this instrument, for the first question are presented six alternatives, two that show a greater initial motivation for this profession and four that express a lower initial motivation. For the author Jesus, the initial motivation for the teaching profession is all the greater because the attended upper course was, from the outset, envisaged as a means to concretize the project of joining this profession.

For the second question, seven alternatives are presented, four that show a greater initial motivation for the teaching profession and three that show less motivation. According to the author, the initial motivation is all the greater as intrinsic factors are the basis of the choice of this professional activity.

The items are preceded by the phrase "teachers of educational training subjects taken together [...]" and are evaluated in a 7-point format (from $1=$ totally disagree to $7=$ strongly agree).Analysis of the results of the instrument that evaluates the Educational Formation Model, to evaluate the model of educational formation, as it was perceived by the trainees, Jesus (1996) formulated a measure, consisting of eleven items that intend to translate a relational model of formation. Taking into account the assumptions that several authors have presented to characterize this model, differentiating it from the normative model of formation.

At the second part, the items are presented in a 5-point Likert format (from 1 $=$ none to $5=$ many) and added in the sense of the highest initial motivation for the teaching profession.

We used the same instrument, with Jesus' permission, on other studies, including Sampaio (2014), with no problems of the Portuguese from Portugal version.

\section{Results and Discussion}

The motivation for an activity depends on the meaning each person attributes to it. It is important to take into account the existence of individual and cultural differences between people when talking about the subject, says Jesus (1996), and agrees with the ideas from Vernon (1973) and Murray (1978).

In this way, we will treat it more comprehensively, not only looking at an aspect but seeking the perspective of a human being with a potential for realization, mentioned by Vygotsky (2007) as Zone of Proximal Development- ZPD. Thus, motivating people to develop activities is one of the basic problems in any process of motor teaching and learning, in the contexts of Physical Education, as proposed by Weinberg \& Gould (2001).

As we point in Table 1, averages do not differ statistically from each other, at the significance level of 5\%, according to the LSD (Adjustment for multiple comparisons: Least Significant Difference equivalent to no adjustments) test.

In our study with Physical Education students, we obtained an overall mean of 
Table 1. Average of the initial motivation of students of physical education of UNIPAMPA, according to the sex and the semester.

\begin{tabular}{ccccc}
\hline & & Average & Default Error & Value p \\
\hline \multirow{2}{*}{ Sex } & Female & $26.421 \mathrm{~A}$ & 0.774 & 0.25 \\
& Male & $25.080 \mathrm{~A}$ & 0.746 & \\
\hline \multirow{3}{*}{ Semester } & Second & $27.152 \mathrm{~A}$ & 0.875 & \multirow{2}{*}{0.017} \\
& Fourth & $27.292 \mathrm{~A}$ & 1.043 & \\
& Sixth & $22.637 \mathrm{~B}$ & 1.227 & \\
\hline
\end{tabular}

Source: Baez (2016).

26.16 points with a standard deviation of 5.36 points.

In our study it was evidenced a valuation of this process, since it obtained an average of 58.85 points $(\mathrm{SD}=7.73)$, being much higher than the study of Jesus (1996), although it is smaller than the average observed in the study of Sampaio (2014) it is important to highlight the licensee to assimilate the new knowledge, it requires time to be able to compare, establish the connections, understand the differences and integrate the knowledge.

Thus, we agree to the affirmation of Sampaio (2014: p. 90):

There was success in the actions that allowed the trainees to reflect on the possible attitudes to adopt in situations of disinterest, indiscipline and school failure as students. On the presumption that the teacher has his personal style; In describing potentially effective alternatives to dealing with problematic situations in the classroom that the teacher can use.

Regarding the initial motivation for teaching practice, the study of Jesus (1996) reports a research by Huberman (1989) with 160 Swiss teachers, in which 9\% of the answers translated passive motivations (lack of better professional alternatives), $28 \%$ translated motivations Materials (going to the profession as a means of subsistence) and $63 \%$ translated active motivations (joining the teaching profession as the desired choice, being the contact with young people the main factor).

Therefore, we can affirm that for these students in Unipampa's Physical Education course, the initial motivation for the teaching profession suffers a decrease in the comparison between the initial semesters of the course. This may be due to experiences and experiences on the part of the academic during the course, because the more advanced the semester in which these academics meet the greater their prospects of insertion in the labor market.

Considering that one learns throughout life, learning becomes one's own life. And personal decisions influence not only the individual but also the life of all mankind. That is why education is strategic.

The objective of Education, according to Lück (2000), is to contribute to the full realization of the human being, in which he is able to integrate the dimensions of the 'I' and the 'world', seeing in his daily problems links with the com- 
plexity of global problems Solve them by solving them locally. Its objective is also to help in the renewal of society by producing new knowledge, seeking answers to solve the problems faced by different human groups.

At this point we consider the education actions to be relevant, especially during the course, according to the perception of the physical education teaching students who are in final semesters, indicating the valuation of pedagogical strategies that the teacher can use. According to Moraes (1996), to innovate, to act pedagogically on new bases involves a profound change of mentality, which is difficult, especially for those who work in the educational field. Thus, it is important to emphasize that the educational models available are of fundamental importance for academic development in a gradual and complete way.

In Table 2 we can see that the averages do not differ statistically from each other, at the significance level of 5\%, according to the LSD (Adjustment for multiple comparisons: Least Significant Difference equivalent to no adjustments) test.

The overall results of UNIPAMPA's Physical Education students point to a positive perspective regarding the professional future, since despite the overall results 29.28 points $(\mathrm{SD}=3.65)$, they are still below the average of the study of Sampaio (2014), 32.03 is a little higher than that of Jesus' study, of 26.93, which points to a formation that makes it possible to envisage a promising professional future for future professionals.

According to data on the educational training model, we again observed that the best means are found in the initial semesters, but it is worth noting that the general results of this variable are above the average of other studies already mentioned. What is worth mentioning is the importance of teacher trainers in this phase of academic life, because through the actions implemented by these professionals will facilitate (or not) how academics will face the obstacles of the teaching profession.

According the data in Table 3, the averages do not differ statistically from each other, at the significance level of 5\%, according to the LSD (Adjustment for multiple comparisons: Least Significant Difference equivalent to no adjustments) test.

Table 2. Average of the educational training model of physical education students of UNIPAMPA, according to sex and the semester.

\begin{tabular}{ccccc}
\hline & & Average & Default Error & Value p \\
\hline \multirow{3}{*}{ Sex } & Female & $58.347 \mathrm{~A}$ & 1.125 & 0.949 \\
& Male & $58.246 \mathrm{~A}$ & 1.084 & \\
\hline \multirow{3}{*}{ Semester } & Second & $61.944 \mathrm{~A}$ & 1.272 & 0.029 \\
& Fourth & $57.490 \mathrm{~B}$ & 1.516 & \\
& Sixth & $57.038 \mathrm{~B}$ & 1.784 & \\
\hline
\end{tabular}

Source: Baez (2016). 
Table 3. Average of the Professional Results of students of Physical Education of the UNIPAMPA, according to the Sex and the Semester.

\begin{tabular}{ccccc}
\hline & & Average & Default Error & Value p \\
\hline \multirow{3}{*}{ Sex } & Female & $29.284^{\mathrm{a}}$ & 0.556 & \multirow{2}{*}{0.813} \\
& Male & $29.101^{\mathrm{a}}$ & 0.536 & \\
\hline \multirow{3}{*}{ Semester } & Second & $29.505^{\mathrm{a}}$ & 0.629 & 0.526 \\
& Fourth & $28.760^{\mathrm{a}}$ & 0.749 & \\
& Sixth & $28.487^{\mathrm{a}}$ & 0.882 & \\
\hline
\end{tabular}

Source: Baez (2016).

Table 4. Average Academic Support of students of Physical Education of UNIPAMPA, according to Sex and the Semester.

\begin{tabular}{ccccc}
\hline & & Average & Default Error & Value p \\
\hline \multirow{3}{*}{ Sex } & Female & $47.977 \mathrm{~A}$ & 1.286 & 0.253 \\
& Male & $50 . .031 \mathrm{~A}$ & 1.239 & \\
\hline \multirow{3}{*}{ Semester } & Second & $52.041 \mathrm{~A}$ & 1.454 & 0.075 \\
& Fourth & $50.003 \mathrm{~A}$ & 1.732 & \\
& Sixth & $45.613 \mathrm{~A}$ & 2.040 & \\
\hline
\end{tabular}

Source: Baez (2016).

In the global division by semester the results presented better values in the second and fourth semesters with 52 points $(\mathrm{DP}=8.20)$ and 50.32 points $(\mathrm{DP}=$ 7.28) respectively, but in more advanced semesters such as the sixth and eighth semesters The scores were even lower with 45.72 points $(S D=9.56)$ in the sixth semester and $48.55(\mathrm{SD}=9.67)$ in the eighth semester. Semesters that already count on the supervised internship discipline.

Here the data results show a concern with the future professional and their ability to reflect on one's own career because this reflection can facilitate the entry and/or permanence of the professional in the labor market. These results are showing trainers that only innovative information and knowledge about the area and its target audience are no longer seen as the fundamental factors of professional development. Therefore, it is necessary a permanent discussion with the reality in search of new alternatives for overcoming the teaching practice.

In Table 4, we cane note that the averages do not differ statistically from each other, at the significance level of 5\%, according to the LSD (Adjustment for multiple comparisons: Least Significant Difference equivalent to no adjustments) test.

Thus, when analyzing the results of Physical Education students, the general results are 49.69 points $(S D=8.75)$, which represents a score well below the studies of Jesus (1996) and Sampaio (2014). 


\section{Conclusion}

As we emphasized from the literature, there are necessarily some basic elements we need to know and take in account when we are in the educational process, ass student (and future teacher) and as teacher (in a future teacher) of these students, including elements such as intrinsic and extrinsic levels of motivation, related to the teaching and learning processes; emotional and cognitive levels of development in some particular scenario but also related to the social local development, in a global constantly evolution.

Based on the research data, in which we seek to identify the responses of the students attending in several semesters of bachelor degree in Physical Education in their process(es) of (re)education, they regard to indicators of interest on their well-being.

We identified that Physical Education students answered the item about Motivation and Pedagogical Support, from the beginning of its formation process (from the second to the last semester), in which we can say that they are constantly (re)structuring academically, in ways to overcome the challenges imposed by their initial educational period, with their interaction with their peers, teachers, in intra and extracurricular contexts, when they are studying at the UNIPAMPA University.

Of course, because this article is an excerpt of the entire thesis, there are missing data about the results of the well-being and quality of life and the results of their affects, by the levels of responses of the self-image and self-esteem instruments.

We recommend possibilities for studies with, for example, attend these students during their entire course, every semester, one of our limitations. Another can be the reports of the teachers involved in the classes every semester and their (qualitative) evaluations about the development of their students.

As a primary take-home message we can emphasize that it is necessary a very good (personal) preparation to deal with students, in general, but more when dealing with these student who are preparing themselves to be a teacher, from the election to the course (preparation courses), during the course (supporting from basic to especial individual issues an necessities), and at the insertion at the work world, at the university, and after this in the (entire) life (including preparation to the retirement, including leisure), as a lifelong support.

Reinforcing the more import data, there is for this sample of student in bachelor course, a high Initial Motivation Assessment and Pedagogical Support, evidences of valorization of their process of Educational Training Model, a positive perspective for their future on Professional Results and they say they have a good internship support.

We emphasize that for the construction of well-being is necessary to construct positive and live university experiences and, for these students, in the process of formation this can be done through the valorization of their practical and theoretical experiences, through the insertion in the school environment, with their participation in study groups and mainly for the professional valuation of the 
chosen area of action, being a better teacher.

\section{Acknowledgements}

To the colleagues who participated in the joint reflection of this manuscript and the scientific revision of the text.

\section{Competing Interests}

Author has declared that no competing interests exist.

\section{Author's Contribution}

The authors made this collaborative text starting with the Baez (2015) Thesis in Education, with the orientation of author 2 and co-orientation of author 3, and we had discussions, and analyzed and interpreted together the data, and prepared the manuscript. All authors read and approved the final manuscript.

\section{References}

Baez, M. A. C. (2008). Relatos de discentes de educação física da PUCRS campus Uruguaiana sobre sua formação [Reports of Physical Education students from the PUCRS Uruguaiana campus about their education]. Dissertação (Mestrado em Educação), Porto Alegre: Faculdade de Educação da PUCRS.

Baez, M. A. C. (2015). O processo de construção do bem-estar e da qualidade de vida durante a formação em Educação Física e suas perspectivas de futuro à luz da Psicologia Positiva [The process of building well-being and quality of life during Physical Education and its future prospects in the light of Positive Psychology]. Tese de Doutorado, Porto Alegre-RS: Faculdade de Educação da PUCRS. http://tede2.pucrs.br/tede2/bitstream/tede/6346/2/475544\%20Texto\%20Completo.pdf

Baez, M. A. C., Stobäus, C. D., \& Mosquera, J. J. M. (2014). A formação inicial em Educação Física para a inclusão e a Psicologia Positiva [Initial education in Physical Education for inclusion and the Positive Psychology]. Lecturas de Educación Física $y$ Deportes (Buenos Aires), 18, 1-8.

Baez, M. A. C., Stobäus, C. D., \& Mosquera, J. J. M. (2016). School Physical Education: Welfare, Motivation and Positive Psychology. Creative Education, 7, 2476-2489. https://doi.org/10.4236/ce.2016.716235

Damasio, A. R. (2011). E o cérebro criou o Homem [And the brain created Man]. São Paulo-SP: Companhia das Letras.

Deci, E. L., \& Ryan, R. M. (1985). Intrinsic Motivation and Self Determination in Human Behavior. New York: Plenum Publishing Co. https://doi.org/10.1007/978-1-4899-2271-7

Deci, E. L., \& Ryan, R. M. (2000). The "What" and "Why" of Goal Pursuits: Human Needs and the Self-Determination of Behavior. Psychological Inquiry, 11, 227-268. https://doi.org/10.1207/S15327965PLI1104_01

Huberman, M. (1989). The Professional Life Cycle of Teachers. Teacher College Records, 91, 31-57. http://hub.mspnet.org/index.cfm/9327

Jesus, S. N. de (1996). A motivação para a profissão docente. Contributo para a clarificação de situações de mal-estar docente e para a fundamentação de estratégias de formação de professores (The Motivation for the Teaching Profession. Contribution to the Clarification of Situations of Teacher Malaise and to the Foundation of Teacher Training Strategies). Aveiro: Estante Editora. 
Lück, H. (2000). Pedagogia Interdisciplinar: Fundamentos teórico-metodológicos (Interdisciplinary Pedagogy: Theoretical-Methodological Foundations) (8th ed.). PetrópolisRJ: Vozes.

Minayo, M. C. S. (2001). Social Research: Theory, Method and Creativity (18th ed.). Petrópolis: Vozes.

Moraes, M. C. (1996). The Emerging Educational Paradigm: Implications for Teacher Education and Pedagogical Practices. Em Aberto, 70, 1-13. http://rbep.inep.gov.br/index.php/emaberto/article/view/2081/2050

Mosquera, J. J. M., \& Stobäus, C. D. (2016). Cognition and Affectivity in the Pedagogical Act-Propositional Aspects for Marist Education. In M. Bonhem- berger, \& $\mathrm{M}$. Mentges (Eds.), Educação Marista: Perspectivas e Desafios (pp. 171-181). São Paulo: FTD.

Murray, E. J. (1978). Motivation and Emotions (4th ed.). Rio de Janeiro: Zahar.

Sampaio, A. A. (2014). Experiences of Teachers and Their Graduates in the Final Education and Transition to the World of Work: Teacher/Student Malaise/WellBeing, Self-Image and Self-Esteem. Doutorado em Educação, Faculdade de Educação da PUCRS.

Sampaio, A. A., Baez, M. A. C., Stobäus, C. D., \& Oliveira, J. R. G. de (2012). Physical Education in High School: Analysis of the Factors That Contribute to the Demotivation and Avoidance of Classes in the City of Uruguaiana. 4 Congresso Internacional de Educação, Pesquisa e Gestão-CIEPG, ISAPG-Instituto Sul Americano de PósGraduação, Ensino e Tecnologia, Ponta Grossa-PR. http://isapg.com.br/2012/ciepg/selecionados.php

Santos, B. S., Antunes, D. D., Mosquera, J. J. M., \& Stobäus, C. D. (2016). Teachers' Motivation Related to Teaching and Learning Processes. Creative Education, 7, 2011-2020. https://doi.org/10.4236/ce.2016.715202

Seligman, M. (2012). Flourish: A Visionary New Understanding of Happiness and Well-Being. London: Free Press.

Vernon, M. D. (1973). Human Motivation: The Internal Force That Emerges, Regulates and Sustains Our Actions. Petrópolis: Vozes.

Vygotsky, L. S. (2007). The Social Formation of Mind. São Paulo: Martins Editora.

Weinberg, R. S., \& Gould, D. (2001). Fundamentals of Sport and Exercise Psychology. Porto Alegre: Artmed.

Scientific Research Publishing

\section{Submit or recommend next manuscript to SCIRP and we will provide best service for you:}

Accepting pre-submission inquiries through Email, Facebook, LinkedIn, Twitter, etc. A wide selection of journals (inclusive of 9 subjects, more than 200 journals)

Providing 24-hour high-quality service

User-friendly online submission system

Fair and swift peer-review system

Efficient typesetting and proofreading procedure

Display of the result of downloads and visits, as well as the number of cited articles

Maximum dissemination of your research work

Submit your manuscript at: http://papersubmission.scirp.org/

Or contact ce@scirp.org 